\title{
Małgorzata Prokosz
}

University of Wroclaw

\section{Significance of Siblings for the Child's Development}

\begin{abstract}
This article analyzed the importance of having siblings in psychological and social growth of a child. It is not a frequently undertaken issue by Polish scholars, hence the point of references is made within foreign studies. The reflections concentrate on the significance of bonds between the siblings, their position in a family and relations depending on the order of arrival to the family, or the child's gender. The question of sibling rivalry is signaled, as well as overtaking parental roles by the eldest child. Moreover, positive aspects of having sibling are stressed, accompanied by problems that can occur upon giving birth to the youngest child. Last but not least, the article provides some guidelines for parents with bigger number of children, so problems within such families can be avoided or minimized.
\end{abstract}

Key words: sibling, development, child.

Family as a subject of research has been for long recognized within sociological, pedagogical, psychological, demographical or philosophical literature. For example, Stanisław Kawula, Józefa Bragiel and Andrzej W. Janke have made the efforts to join research concepts concerning families, publishing in 2006 a study "Family Pedagogy. Areas and spectrum of problems". The quarterly "Pedagogika Rodziny" has been published since 2011, managed by Henryk Cudak, the editor-in-chief. The question of the status of family pedagogy is raised by many authors [Truskolaska 2012, pp. 89-114], most frequently referring to the family as an upbringing environment with attention paid to the parental values and attitudes, including social roles of mothers, fathers or the importance of the seniors, i.e. grandmothers or grandfathers, within the process of upbringing. The research areas also tackle families affected by problems or social threats 
such as unemployment, diseases, disability, or necessity of migration, that often lead to the dissolution of the family structure, disturbances or even pathologies. Scientists in their studies often not only signalise the problems, but indicate ways of providing support for families at risk, or already in crisis.

Therefore, a family is treated as a complimentary complexity with significant division between the (better or worse functioning) adults and a child (children) that need to be taken care of the best possible way according to the principles and functions. If nurturing is insufficient, it needs to be compensated. Considering a child as an object is omitted in these reflections, as in such cases a child is perceived solely as an object of the family, educational system or social security influences, deprived of its autonomy and independence.

Polish research projects within families seem to neglect the issue of the children themselves, being more consumed with it as a focus of adults' influences, or in a context of relations with the sick, or disabled, siblings. Appropriate relationship with healthy siblings do not, unfortunately, provide an impulse for research for majority of scholars. It can be related to the fact that contemporary families of the $21^{\text {st }}$ century embrace both parents and one child, what results from many aspects, often concerned within literature such as economic or social factors, organizational problems in providing care, or etc. Nonetheless, it is worth emphasising that sibling is equally crucial for the psychological as well as social development of a child.

\section{Early Bond}

The well-know story of two twins, Kyrie and Brielle Jackson, that were born premature, 12 weeks before due date in a hospital in Massachusetts, on October 17, 1995, began with little chances expressed by doctors for their survival. After delivery, Kyrie was strong and put on weight quickly, whereas her sister was much weaker and smaller, having problems with vascular and respiratory systems. Upon critical moment the nurse placed the stronger girl into the incubator of the dying Brielle. When Kyrie put her arms around her sister, something unusual happened, as the condition of the weaker twin improved. Today, the inseparable sisters are 19 years old and their love is still growing strong. It should not arise amazement as the bond between twins is usually particularly powerful and longlasting [Kawula 2006, pp. 273-282; Brazelton, Sparrow 2014, p. 177].

It is worth to recall the research of an American pediatrician and psychoanalytic, T. Brazelton [2011], who established the Neonatal Behavioral Assessment Scale (NBAS), frequently referred to as "Brazelton", applied in pediatric diagnostic since 1973. It is a test revealing the dynamics of a child's growth by measuring the reactions of the newly born baby to different stimuli such as a light, a rattle, moving ball, etc. It is founded in the premise that individuality of each child's must 
be respected and that infants communicate through their behaviour. According to Brazelton, a child should strike up regular social contacts during the second year of life. Moreover, many behavioral patterns and skills crucial form the social, intellectual and emotion perspectives, are acquired through imitation. If a child has older siblings, it happens naturally, although the relation between the siblings is subject to the style of the functioning of the entire family. Establishment of friendly bonds depends on the parents, their accepted principles of upbringing and sensitivity to the experiences of the younger and elder children. Hence, the elder sibling plays a big part in the growth of the younger babies, providing a role model to be imitated. The successes and - in the long run -life accomplishments of the elder one makes such life achievements more probable for the younger child, or children.

Relations between siblings are very important as they are the most long-lasting of all relationships [Depczyńska 2011, p.157]. It results from the fact that siblings, especially in case of insignificant age difference, provide the most crucial social environment for each other within the home setting [Birch 2007]. Still, the age itself is not always the most appropriate indicator of the bond, as there are strong relations between siblings with a wide age gap. The elder sibling is not only an object in a friendly relationship or partner to play but serves as a role model as far as development of hobbies and different interests are concerned [Depczyńska 2011, pp. 169-170]. Helen Bee [2004] distinguishes 5 types of relations between the siblings, namely the care-giving, a pal-relation, criticizing, competing and spontaneous one. Its nature depends from the parental approach to own children and roles assigned to each child in a family. It is also worth to remember that within each type of relations there is a strong bond existing between given members.

\section{The Order of Delivery and Child' Position in a Family}

Within a family, as in any other social group, there are relations between its members accompanied by a given hierarchy, that is subsequently reflected in the privileges and obligations of each of its members. It also concerns the youngest remember, i.e. the latest delivered child in a family [Richardson \& Richardson 1999, Birch 2007].

Change in the structure and hierarchy in a family is generated by the very fact of arrival of the newly born baby. Thus, each child comes to the world and is brought up in totally different circumstances, consequently functioning in different conditions than its siblings. At the same time, pedagogical measures, applied by the parents to bring up the first child do not have to serve its function and become efficient in case of the next child. It is conditioned by different causes and factors resulting from the fact of being a brother or a sister. Parents often 
believe their children are different, although theoretically, they function in the same house and are brought up in similar manner, under the same circumstances and by application of the same stimuli. They seem to neglect the obvious fact that since the day of arrival, a new family member functions in completely different circumstances than his brother or sister, when the latter were the only children. Individual features of a child are also in this regard of great importance, as much as the parental attitudes, gender or age that differs both of the children [Brazelton, Sparrow 2014, pp. 103-111].

Arrival of the new baby lead to re-definition of own place for all the family members. It is obvious that the more children, the greater diversity of preferences and social roles a family has to face and fulfill. The elder children begin to experience increasing independency, sense of self-esteem, and productivity of own actions. The first children are expected to behave more mature and responsible than their younger siblings. They are often assigned to the tasks of taking care of their younger sisters or brothers when their parents are absent. Consequently, they can experience greater self-confidence and self-acceptance thanks to which it can be easier for them to find own place amongst siblings or the family structure. The elder children are more often than the younger ones submissive towards their parents, a feeling accompanied by a natural tendency to take care of the younger brothers or sisters. It is commonly expected by the parent or the elder child to suppress hostility towards the newly born baby, to present caring attitude, expressing affection and tenderness. In such way, however, the youngest baby is made happy at the cost of the elder one. Consequently, the younger baby has its period of childhood extended, whereas the elder experiences the opposite, i.e. shorter period of carless childhood.

The second child is usually quieter, crying less at night. It naturally accepts the amount of time spent by parent at its presence, as it has no knowledge how much time they devoted to the first child. Such baby learns from the first days of its life that a brother or a sister is the main "source of entertainment", hence the elder sibling is the main object expected by the young one to launch a common play and games. If the elder one refuses, the younger baby can play alone in quiet and engaging manner for itself. It is often the reason why parents claim their second child is "an angel", as they had to devote a lot of time to the first one and play with it all the time, whereas the second one can play alone, so they often feel as the baby was not present at all. Obviously, it is more difficult for the second baby particularly during the first years of life - to present with some accomplishment as usually it is the older child that has such accomplishment already expressed. The younger usually think that he is marginalized by own brother or sister, wearing clothes after the older one, or playing with their toys. Such baby often feels that its life is dull as the first child has just begun attending preschool or started the 
first grade at primary school, so it is far more exciting. The younger one usually losses the "battles" with the older one, however it can also mobilize him or her to take up another activity. For example, in order to be acknowledged the best pupil by their mother or father they study harder than the older sibling. It does not, however, grants a success for such children - often quite the contrary, but if an opportunity to accomplish in other discipline (including sports, art classes, or etc.) is spotted, they usually succeed. Thanks to such rivalry between siblings, the younger can protect themselves very well against the peers, both verbally and physically. They deal with the group better too, not trying to make others inferior, but rather cooperating according to the set up rules.

The middle children, especially if they have experienced the stage of being the younger for a short period, encounter more difficulties in own life than the rest of the siblings due to their position, as they are most frequently subject to negligence. On the other hand, the positive trait of their growth lies in the lack of pressure from their parents, so they do not set for themselves excessive demands or standards. They also function well within the group due to their experiences in contacts with two different personalities of their siblings. Moreover, they acquire negotiating skills they use in further life. If the middle children are of other gender than their siblings they can get more attention than the rest of the offspring, receiving support from the elderly sibling and being admired by the younger ones. Still, the middle baby requires a particular attention from their parents.

The youngest babies, particularly if there is a big age gap between the youngest and the rest of the siblings, often become spoiled, not only by their usually advanced in age parents or grandparents - but by their siblings, especially if there is more than one of them. Thanks to it they come to a realization that their desires must be fulfilled, hence they demand it from others. The younger child is often a "family darling", i.e. a mascot, which is a charming role, however if it becomes dominant in the child's personality, it makes parents turn blind eye to other, often suppressed needs and desires, such as to have a real pet to take care of. The family "darling children", favored by parents and other people from the family and neighboring circle, are usually bolder than other children, more often express friendly attitude to the surrounding and manifest greater initiative and self-confidence. However, the younger children tend to impose own will upon other family members and other people, particularly colleagues. The youngest children are more oversensitive and expect different support from their parents or siblings, or from others from the nearest surrounding when they grow up and acquire social maturity. Still, the usually reveal greater optimism towards life, believe in positive future and in the fact that various needs can be always fulfilled by the caring parents or elderly siblings. Apart from having such 
positive features, the "darling-children" can be more susceptible to egoism while dealing with others, in comparison with those less noticed or rejected by the social surrounding. These two negative traits of personality can result in lack of acceptance of such child amongst the peers, or later, by their social environment.

\section{Sibling Rivalry}

An elder child most frequently perceives the new family member as an ally, but paradoxically also as a rival. The relations between siblings can reflect positive relations between others (such as solidarity, equality or brotherhood), but on the other hand, it is good to remember that "for all people to live like brothers is just a dream of someone who has no brother". And despite to express solidarity does not require parental assistance, it is quite the opposite in case of rivalry. Sibling rivalry is one of the most common causes of the children's bickering, as mentioned by Robin Baker and Elizabeth Oram [2001, pp. 187-190]. Its range is subject to the age difference, gender and genetic kinship. The smaller the age difference the more corresponding their needs are, hence the pressure towards rivalry is bigger due to more or less equal chances. There is always greater probability of a fight between two sisters or brothers than amongst children of different age.

If children do not share common genotype (e.g. reconstructed families), their predisposition to rivalry is greater, similarly as in the case of one mother and two genetic fathers, when children feel less familiar to each other, thus the need for rivalry (domination) is higher.

Generally, misunderstandings between the sibling and rivalry are inescapable [Faber, Mazlich 1995]. They provide a developmental key function as long as they do not solely reflect unfair approach to children and conflicts between their parents. Small arguments teach how to deal with difficult situations, and thanks to them a child learns and becomes aware on its nature, revealing the efficiency of own actions, learning what makes the siblings happy and what irritates them. Such child becomes aware how to cope with own reactions, hence as it grows up, it is capable of recognizing others' reactions better too. Parents should not allow the conflicts between siblings to escalate, hence physical violence or fights should be dealt with immediately. If it reoccurs, it can affect mentality of such child that will feel bitterness to own siblings and might be willing to avoid contact with them in the future. The nature of conflicts differs, depending on the children's gender. Sisters usually establish a cordial bond, expressing tenderness towards younger brothers, whereas brothers more often compete with each other, particularly when the age difference is not big.

While solving conflicts, parental roles are of paramount importance. Hence, to limit the possibility of occurrence of conflicts it is important to fairly praise children, as equal as possibly, so the younger could admire the elder sibling 
without the sense of envy. It should be stressed, moreover, that each of the child is special and when one will be favored, it can generate reluctance between the siblings when they grow up. The elder child should not perform parental tasks while taking care of the younger child, although asking for episodic assistance is advisable.

\section{Siblings and Parental Roles}

An elder child usually assists parents in care-giving activities over younger child or children. It is both natural and useful for the elder as such child becomes more responsible and resourceful. Nonetheless, it also happens that the elder overtakes too many responsibilities when the parents are overload with professional activities and their opportunities to provide appropriate care and nurturing for children at home are limited. Moreover, situation when parents are absent for long periods at home are becoming more and more common, also due to their migration. It is followed by the necessity of fulfilling the car-giving tasks by the other members of the family, including elder children. Another problem occurs within foster kinship-related families [Jarzębińska 2013, p. 29] when the eldest child takes care of the sibling due to insufficiency of the action provided by biological parents. It is an issue that concerns adoptive families too [Brazelton, Sparrow 2014, pp. 93-102], particularly when a family with children is entered by a new sibling. Such occurrence can also affect socialization facilities, e.g. a family group mode. Despite constant care provided by the staff, the truly father's or mother's role is often expressed and exercised by the elder brother or sister. On one hand it is undoubtedly favorable due to maintenance of appropriate emotional bonds, but in the long run the elder child can be burdened with tasks that are usually assigned to parents.

\section{Positive Aspect of Having Siblings}

Taking into consideration the current reflections there are many positive aspects of having a brother or sister that can be stressed [Faber, Mazlich 1995]. Sibling provides with emotional support in crisis and difficult situations. When a death or divorce affects given family, relations with a brother or a sister allow to go through such trauma quicker and easier. Elderly sibling provides support for the younger, preparing to new experiences such as attending preschool, entering educational system, or giving advice on managing new, unfamiliar situations. Moreover, it helps in practicing emotional expression and growth of trust.

Functioning with a brother or a sister strengthens self-esteem amongst children as having someone who loves us unconditionally and almost adores us, helps to build up the self-esteem and high level of self-confidence, as it often happens among siblings. Younger children learn from the elder through imitation 
but the relations works both ways, i.e. the elder children, helping their younger sibling in troubles, develop their intellectual and emotional skills, thus they both inspire themselves to explore the reality around creatively.

Having sibling is crucial in shaping social skills, as children, thanks to observation and imitating patterns, learn how to behave in given situations that involve interpersonal reactions. In most cases the younger sibling imitate the patterns of behaviour and rules of social coexistence from their elder brothers or sisters, hence such child is taught by the elders how to share, fight for own cause, make compromise or wait for own turn. A child realizes it is possible to love someone and still argue with such person, hence becomes familiar with wide range of emotions and feelings.

Each relation between sibling is subject to arguments or some misunderstandings. After such, it is always important to solve the conflict and make up as it will help to teach children appropriate argumentation, compromise and expression of own points of views. Both the elder as well as the younger child can, by this mean, acquire experience helpful in dealing with reactions of the other person, becoming aware of own character and how to live among others.

Common life of brothers and sisters under the same roof is advantageous in comparison with those who have no sibling or have one-gender siblings, due to the opportunities for the first group to get to know the mechanisms determining the specificity of the other gender. Practically, it allows them to lessen the anxiety towards the other sex and acquire conversational as well as communicative skills.

\section{Hypothetical Threats resulting from Having Sibling}

Having sibling can also lead to different kinds of problems, conflicts or competition

[Baker, Oram 2001, Brazelton, Sparrow 2014, Faber, Mazlich 1995]. The very arrival of the new baby comes as a shock to the other children, refer to as a "dethroning shock", what implies such child can feel abandoned by own parents. It does not understand why it should share own toys with the younger sibling, not to mention "sharing" parents' attention. Such child often rebel against own mother that at early stage begins to pay a lot of attention to the younger member of the family, or against the father that bathes such younger brother or sister in the evenings. Moreover, parents fear that after the arrival of the new baby they will not cope with devoting enough time, energy and attention to the older child. Hence, a brother or a sister is not only a partner to play with, but it can turn into a rival that fights with own sibling for engagement and interest of the parents in its own issues. Arguments are unavoidable and provide a key element of child's development within a family. However, if the conflicts increase and parents ignore them, there is a risk that children will feel grudge against each other and, as a result, avoid each other's presence. 
No matter what kind of problem exists between the siblings, it is always worth to talk to the elder child on future changes and arrival of the new family member, consequently taking care of each member of the family.

\section{Guidelines for Parents}

Having two or more children is a real challenge for parents, as they have to pay attention not only to the material needs of their offspring, but also provide them with appropriate psychological comfort and conditions for development. Ensuring sense of security and stimulation of growth appropriate to the age and children's specificity are of key importance in this regard. Hence, delivery of a new baby is accompanied by revaluation of already existing relation and establishing new ones, based on number of cardinal principles determining priorities of appropriate growth [Brazelton, Sparrow 2014, pp. 103-111, Faber, Mazlich 1995].

As far as the elder child is concerned, it is important to maintain its sense of being a child, regardless of functioning as the oldest one. Parents cannot demand from such child to feel constantly responsible for the sibling and fulfill adults' tasks. A child, no matter the age, its accomplishments or position in a family, should experience love and care from own parents. It must be remembered that each child is different and should be appreciated on the ground of its uniqueness. It is also important for such child not to feel burdened with the problems and worries of adults, but should be rather acknowledged as someone whose opinion is important. The eldest child should be motivated and encouraged to undertake autonomous activities within different range and manage individually relations with peers. Nonetheless, it should not be criticized, nor urged. The eldest child cannot be assigned to too many duties as it will simply not be able to handle it.

The middle child should be aware that parents devote enough time and attention for it. It must be, moreover, kept aware of own talents, which could be used and applied in the family life by assigning such child to given tasks and obligations according to the manifested skills. Besides, teaching calm and precise defining of own needs and consequences to achieve them are of key importance. Parents should make such child aware that it is important to define own place in the world, even if it takes place at the cost of losing others' approval. The middle child, as any other human being, has the right to complain, and it is important for parents to remain open, understanding and supportive.

Appropriate approach towards the youngest child should focus on stimulation of its intellectual growth and abilities. Adults should appreciate each own, creative activity of a child that tries to equal the elder siblings. Such child should be praised for any signs of independence and implementation of own action as well as making independent decisions. Since it is the youngest child, it does not always succeed in own efforts, thus parents should provide comfort for their child in difficult situations. 


\section{Małgorzata Prokosz}

The youngest child should also learn when to undertake individual activities and when to ask others for help and advice. Thanks to it, parents will remain calmer, as over the course of time, such child will become more and more independent and grow up properly. Hence, it is important for such child to learn how to accept criticism and how to gain valuable and useful information from such statements, as that can help to act constructively and efficiently.

\section{Summary}

Arrival of a new baby changes the life of the entire family. It is an important moment for the parents as they acquire awareness that their first child has someone close to him, apart from him. They feel calmer, in comparison to the delivery of their first baby, and more confident while performing care-giving and nurturing tasks (such as changing the nappy). Sometimes only after the delivery of the second child they feel relived and can fully enjoy their maternity or fatherhood. Bringing up two or three children is a complicated and multidimensional process. At the same time, it is a great opportunity for children to learn how to deal with problems better, shape their personality and character more productively, what can in turn undoubtedly contribute to their future way of managing own life. Having a brother or a sister also implies a completely new range of duties, providing a great opportunity to practice social skills such as cooperation, but also a struggle to fulfill own needs. Nonetheless, it is of paramount importance that there should be a strong bond between the siblings, that would provide them with the sense of security, shaping the awareness that no matter what happens, they will be always someone they can turn to. Elder brothers or sisters often facilitate their younger sibling to deal with emotionally difficult situations, what empowers improves their sense of security.

I hope that this topic will be met with the scholars' interest as the signaled questions solely mark a beginning to further studies and scientific explorations.

\section{Bibliography}

Baker R., Oram E. (2001), Wojny driecięce. Macierzyństwo, ojcostwo i waśnie rodżinne, Dom Wydawniczy REBIS, Poznań.

Bee H. (2004), Psychologia roz̧woju cz̧towieka, Wydawnictwo Zysk i S-ka, Poznań.

Birch A. (2007), Psychologia rozzojowa w zarysie, Wydawnictwo Naukowe PWN, Warszawa. Brazelton, T.B., Sparrow J.D. (2014), Rywalizacja rodzeństwa. Zakończ kłótnie i ciesz sie spokojem w domu, Gdańskie Wydawnictwo Psychologiczne, Sopot.

Brazelton, T.B., Nugent, J.K. (2011), The Neonatal Behavioral Assessment Scale, Mac Keith Press, Cambridge.

Depczyńska D. (2011), Stymulowanie zainteresowań dzieci w wiekuprzedsžkolnym zainteresowaniami starszego rodžeństwa, „Pedagogika Rodziny. Family Pedagogy”, nr 1(3/4), pp. 151-171. 
Faber A., Mazlish E. (1995), Rodzeństwo bez rywalizacji. Jak pomóc własnym dzieciom żyó w zgodzie by samemu żyć zodnościq, Media Rodzina, Poznań.

Jarzębińska A. (2013), Rodz̨eństwo w roli rodz̧cielskiej, „Problemy OpiekuńczoWychowawcze", nr 2, pp. 29-31.

Kawula S., Bragiel J., Janke A.W. (2006) Pedagogika rodziny. Obszary i panorama problematyki, Wydawnictwo Adam Marszałek, Toruń.

Kawula S. (2006), Warunki wychowawcze bliźniat w rodzinie [in:] S. Kawula, J. Bragiel, A.W. Janke, Pedagogika rodziny. Obszary i panorama problematyki, Wydawnictwo Adam Marszałek, Toruń.

Richardson R.W., Richardson L.A. (1999), Najstarsze, średnie, najmtodsそe, Gdańskie Wydawnictwo Psychologiczne, Gdańsk.

Truskolaska J. (2012), Kierunki badań empirycznych z. zakeresu pedagogiki rodziny w Polsce w latach 1992-2010 [in:] A. Ladyżyński (ed), Pedagogika rodziny - in statu nascendi czy u₹nana subdyscyplina?, Oficyna Wydawnicza ATUT, Wrocław. 